\title{
PRIORITISING COMPETITIVE STRATEGIES BASED ON THE ANP APPROACH: A CASE OF THE LATVIAN TELECOMMUNICATION COMPANY
}

\author{
Irina Voronova ${ }^{1}$, Vladimirs Shatrevich ${ }^{2}$, Mihails Gavrilovs ${ }^{3}$, \\ Viktorija Skvarciany ${ }^{4}$ \\ ${ }^{1,2,3}$ Department of Innovation and Business Management, RTU, \\ Kalnciema street 6, Riga, Latvia, \\ ${ }^{4}$ Faculty of Business Management, VGTU, Vilnius, Lithuania \\ E-mails: Irina.Voronova@rtu.lv; Vladimirs.Satrevics@rtu.lv (corresponding author); \\ Mihails.Gavrilovs@rtu.lv; viktorija.skvarciany@vgtu.lt
}

\begin{abstract}
The present study provides a comparative analysis of development strategy selection and presents an overview of multiple-criteria decision analysis (MCDA) in strategic management. The main aim of the paper is to use the analytic network process (ANP) as one of MCDA methods for determining the best strategy. Based on expert opinions and analytic hierarchy process (AHP), the authors have identified and evaluated SWOT analysis factors used for the development of a company strategy. To investigate the interaction of external and internal environment, the authors have used the ANP that allows obtaining relative measurement of the influence of SWOT elements. The ANP is useful with regard to interdependent relationship between multi-objectives and multi-stakeholders' environment. The algorithm of quantitative evaluation of telecommunication company strategies is also presented in the paper.
\end{abstract}

Keywords: multiple-criteria decision analysis, strategic management, SWOT, AHP, ANP, quantitative analysis.

JEL Classification: C44, C61, M19, M21, O20, O21.

\section{Introduction}

SWOT analysis is often used as one of the popular methods for strategy formulation. However, one of the major issues of SWOT analysis is related to quantification and prioritization of factors and alternatives. Due to this weakness of SWOT analysis, scientists are combining SWOT with other methods and techniques. One of more accurate methods of quantification and prioritization of factors is A'WOT, i.e., a hybrid method combining the SWOT analysis and the Analytic Hierarchy Process (AHP). Kurttila, Pesonen, Kangas, and Kajanus (2000) first developed the SWOTAHP method and successfully used this hybrid methodology to assess strategic alternatives (Kurttila et al., 2000). The main objective of the present paper is to use the analytic network process (ANP) for determining the best strategy. The following tasks are put forward: to identify and evaluate SWOT factors using the analytic hierarchy process; to investigate the interaction of external and internal environment with the ANP approach; to compare the used methods and make recommendations; and finally to present the algorithm of quantitative evaluation of telecommunication company strategies.

SWOT analysis combined with ANP is one more approach proposed to determine the factor weights of dependency or independency by creating more advanced priority determination in hybrid models. Assuming that interdependence of the factors that are used in SWOT analysis can impact the selection of a final strategy, Yuksel and Dagdeviren proposed the hybrid SWOT-ANP model for ranking the strategies, factors and subfactors (Yüksel \& Dağdeviren, 2007). Later the ANP approach was widely adopted and exploited by many scientists to determine relative importance of strategic factors as the basis of prioritizing the previously formulated strategic options (Al-Refaie, Sy, Rawabdeh, \& Alaween, 2016; Catron, Stainback, Dwivedi, \& Lhotka, 2013; Di Lallo, Maesano, Masiero, Mugnozza, \& Marchetti, 2016; Gottfried, De Clercq, Blair, Weng, \& Wang, 2018; Grošelj \& Zadnik Stirn, 2015; Hejazi \& Lak, 2014; Moghimi, Sobhanollahi, \& 
Ghodratnama, 2014; Shahabi, Basiri, Kahag, \& Zonouzi, 2014; Wang et al., 2017; Wijnmalen, 2007; Zhü et al., 2016; Živković, Nikolić, Djordjević, Mihajlović, \& Savić, 2015). Although the ANP method is used by the authors, the SWOT-ANP combination has also some acknowledged disadvantages: the mutual dependency of two factors is treated as the reciprocal value in the map of an interrelation network and that does not always correspond to reality. The same problem also arises when normalizing the unweighted supermatrix in ANP, where the same relative importance is assigned to each cluster. The SWOT-ANP-AHP models have also some drawbacks when experts are evaluating priority determination among factors and alternatives in the case of a huge number of factors. Experts involved in the evaluation process need to perform a mass of accurate identification procedures among factors that could be very exhausting. Another issue is the evaluation uncertainty, when expert cannot quantify relative influence or priority of the factors very accurately and spends a lot of time on the evaluation process. In this case, experts could be allowed to use a fuzzy scale (the average opinion of group of experts is a fuzzy value obtained by the aggregation of individual opinions). This is one of the major reasons for fuzzy approach application in AHP and ANP methods with SWOT. The combination of ANP and AHP for SWOT in a fuzzy environment is also widely adopted by many scientists nowadays (Arshadikhamseh \& Fazayeli, 2013; Arsić, Nikolić, \& Živković, 2017; Babaesmailli, Arbabshirani, \& Golmah, 2012; Cayir Ervural, Zaim, Demirel, Aydin, \& Delen, 2018; Cebeci, 2009; Fouladgar, Yazdani-Chamzini, \& Zavadskas, 2011; Haile \& Krupka, 2016; Yang, Shieh, Leu, \& Tzeng, 2008; Ren, Gao, Tan, \& Dong, 2015a; Ren, Tan, Goodsite, Sovacool, \& Dong, 2015b; Sevkli, Oztekin, Uysal, Torlak, Turkyilmaz, \& Delen, 2012; Wang, Liu; \& Cai, 2015).

\section{SWOT, ANP and AHP models}

As a systematic method, the SWOT analysis can help users identify the internal and external environment and provide a basis for the development of a strategy (Andrews, 1971). The most important step of the SWOT analysis is to identify the strengths, weaknesses, opportunities and threats of a particular industry, list them in a matrix and then determine the SO (strengths-opportunities), ST (strengths-threats), WO (weaknessopportunities), WT (weakness-threats) strategic program (Hill \& Westbrook, 1997). MCDA methods allow ranking the determined strategies and factors. AHP, as a hierarchical weighted decision analysis method proposed by Saaty (Saaty, 1989), is the most widely used MCDA method and combines qualitative analysis with quantitative analysis (Ho, 2008). The global priorities of criteria, sub-criteria and alternatives are synthesized using the eigenvalue method (EM). The EM is the solution of the eigenvalue problem:

$$
A w=\lambda_{\max } w
$$

where $\lambda_{\max }$ is the largest or principle eigenvalue of the pairwise comparison matrix and $w$ is the corresponding principle eigenvector.

The $C R$ (Consistency Ratio) of matrix $A$ is used to check judgment inconsistency. $C R=$ $C I / R I$, where $C I=(\lambda \max -n) /(n-1)$ and $\lambda \max$ is the maximal eigenvalue of $A$. RI (Random Index) is an experimental value, which depends on $n$ (Saaty, 1989). According to the scale principles in Table 1, a comparison of pairs is derived in matrix. ANP is a newer tool used to solve multi-criteria problems. It is a type of system decision analysis, which combines qualitative and quantitative factors based on the AHP (Saaty, 2004). The hierarchical structure of the AHP is formed using a top-down linear structure, whereas the ANP network structure is a nonlinear structure with factors placed in all directions (Sevkli et al., 2012).

Table 1. Fundamental Scale of AHP (Saaty, 1989)

\begin{tabular}{|c|l|}
\hline $\begin{array}{c}\text { Intensity of } \\
\text { Importance }\end{array}$ & \multicolumn{1}{c|}{ Definition } \\
\hline 1 & Equal importance \\
\hline 3 & Moderate importance \\
\hline 5 & Strong importance \\
\hline 7 & Very strong importance \\
\hline 9 & Absolute importance \\
\hline $2,4,6,8$ & $\begin{array}{l}\text { Used to express intermediate } \\
\text { values }\end{array}$ \\
\hline reciprocals & $\begin{array}{l}\text { The scale between } x_{i} \text { and } x_{j} \text { is } \\
r_{i j}=1 / r_{j i}\end{array}$ \\
\hline
\end{tabular}

ANP not only solves the issues that can be solved by AHP but also considers the interaction with and dependency on each influencing factor in decision-making (Chen \& Yang, 2011).

\section{Methodology}

The proposed integrated framework used in the present study is graphically shown in Figure 1. 


\begin{tabular}{|c|c|}
\hline $\begin{array}{l}\text { Step 1: Forming a group of experts to assess } \\
\text { SWOT factors and select strategies (Table 2) }\end{array}$ & \multirow{3}{*}{$\begin{array}{l}\text { Phase } 1 \\
\text { SWOT } \\
\text { creation }\end{array}$} \\
\hline $\begin{array}{l}\text { Step 2: Determining the SWOT factors and } \\
\text { sub-factors (Table 3) }\end{array}$ & \\
\hline $\begin{array}{l}\text { Step 3: Determining strategies by using } \\
\text { SWOT matrix (Table 4) }\end{array}$ & \\
\hline $\begin{array}{l}\text { Step 4: Constructing pairwise factor compari- } \\
\text { son of the SWOT (Table 5) }\end{array}$ & \multirow{4}{*}{$\begin{array}{l}\text { Phase } 2 \\
\text { A 'WOT }^{\prime} \text { ' creation }\end{array}$} \\
\hline $\begin{array}{l}\text { Step 5: Determining the interdependent } \\
\text { weights of the SWOT factors (Table 6) }\end{array}$ & \\
\hline $\begin{array}{l}\text { Step 6: Constructing the local importance de- } \\
\text { grees of the SWOT sub-factors (Table 7) }\end{array}$ & \\
\hline $\begin{array}{l}\text { Step 7: Determining the overall weights of the } \\
\text { SWOT } \quad \text { sub-factors } \quad \text { (Table }\end{array}$ & \\
\hline $\begin{array}{l}\text { Step 8: Determining the importance of sub- } \\
\text { factors for strategies (Table 9) }\end{array}$ & \multirow{5}{*}{$\begin{array}{r}\text { Phase } 3 \\
\text { Best } \\
\text { strategy } \\
\text { selection }\end{array}$} \\
\hline $\begin{array}{l}\text { Step 9: Evaluating interdependence of sub- } \\
\text { strategies (Table 11) }\end{array}$ & \\
\hline $\begin{array}{l}\text { Step 10: Ranking sub-strategies according to } \\
\text { overall priority (Table 12) }\end{array}$ & \\
\hline Step 11: Determining the final rank & \\
\hline Step 12: Selecting the best strategy & \\
\hline
\end{tabular}

Figure 1. The integrated SWOT-ANP framework (source: created by the authors based on Arsić, Nikolić, Mihajlović, Fedajev, \& Živković, 2018, 2017; Cayir Ervural et al., 2018; Grošelj \& Zadnik Stirn, 2015; Yüksel \& Dağdeviren, 2007; Sevkli et al., 2012)

The steps of the proposed framework are partially adapted from the best practices in the latest literature (Arsić et al. 2018, 2017; Cayir Ervural et al. 2018; Grošelj \& Zadnik Stirn, 2015; Yüksel \& Dağdeviren, 2007; Sevkli et al., 2012).

\section{Application of AHP and ANP to SWOT matrix}

The proposed methodology was applied to Turkey's energy sector in order to determine the national energy strategic plan. Initially, the authors of the present paper reviewed the literature to establish a comprehensive understanding of the strategic energy policy determinants. Then a rich and diverse committee of experts from the energy sector (both government and commercial) was identified. In this way, the authors intended to cover all factors and sub-factors that might have an effect on the optimal outcome. The SWOT analysis is a powerful strategic tool and it provides a means to identify and organise information on key issues that are important for achieving the objective. Hence, this analysis helps identify the strengths and/or the weaknesses of the organisation, which are called internal factors, and also help uncover the opportunities and/or the threats towards the organisation, which are called external factors.

\subsection{Forming a group of experts}

To assess SWOT factors and select strategies, a group of experts was formed. It comprised specialists of the company and specialist consultants. The number of experts in accordance with the principles of Gestalt (Merton, Fiske, \& Kendall, 1990 ) should be in the limit of 10 people (usually $7 \pm 2$ ). Selection of candidates for a group of experts can be carried out by various methods (Ivlev, Kneppo, \& Barták, 2015).

The authors of the present study propose developing a simple method of self-assessment and calculation of the coefficient of competence. Candidates (initiating the development of a strategic development plan) are asked to answer the question: How do you assess the level of skills in the field of strategic management? The results of the survey of candidates for experts and calculation of the competence of experts and a group of experts are given in Table 2 .

Table 2. Formation of a group of experts

\begin{tabular}{|c|c|c|c|c|c|c|c|c|c|c|c|}
\hline \multirow{2}{*}{ 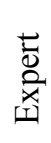 } & \multicolumn{3}{|c|}{ Criterion 1} & \multicolumn{3}{|c|}{ Criterion 2} & \multicolumn{3}{|c|}{ Criterion3 } & \multirow{2}{*}{$K_{i}$} & \multirow{2}{*}{ 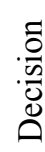 } \\
\hline & 1 & 0.5 & 0 & 1 & 0.5 & 0 & 1 & 0.5 & 0 & & \\
\hline E1 & 1 & & & & 1 & & & 1 & & 0.67 & + \\
\hline E2 & & 1 & & 1 & & & & 1 & & 0.67 & + \\
\hline E3 & 1 & & & 1 & & & 1 & & & 1.00 & + \\
\hline E4 & 1 & & & 1 & & & & 1 & & 0.83 & + \\
\hline E5 & & 1 & & & 1 & & & & 1 & 0.33 & - \\
\hline E6 & & 1 & & 1 & & & 1 & & & 0.67 & + \\
\hline E7 & & 1 & & & 1 & & & & 1 & 0.33 & - \\
\hline
\end{tabular}

Rule for the decision to include $(+) /$ not include $(-)$ an expert in the group, where:

$i$ - assessment of the competence of the group of experts;

if $0.67 \leq K_{i} \leq 1.00$ an expert is added to the group; if $K_{i}<0.67$ an expert is not added to the group.

Assessment of the competence of the group of experts $-K_{i}$

Assessment of the competence of the group of experts

$K_{k g}=\frac{1}{n_{x}} \sum_{i=1}^{n_{x}} K_{i}=0.76$,

where: $K_{i}$ - competence assessment of $i$ expert; $n_{\mathrm{x}}-$ the number of selected experts in the group.

Assessment criteria:

1. Theoretical knowledge of strategic management.

2. Practical experience of strategy formulation.

3 Conceptual skills. 
The group of experts is formed of five experts and its competence is more than the normative value $\left(K_{i}=0.67\right)$ (Postnikov \& Spiridonov, 2013).

The authors used a geometric mean method (GMM), also called the approximate eigen vector method for judgement matrices (Saaty, 2005):

$$
a_{i j}^{a}=\sqrt[n]{a_{i j}^{1} a_{i j}^{2} \ldots a_{i j}^{n}},
$$

where: $n$ - the number of experts participating in decision making of SWOT matrix $(n=5) ; a_{i j}^{n}-$ assessment of factors $i$ row and $j$ column of the matrix.

\subsection{Main steps of the proposed framework}

The main steps of the proposed methodology and its specific implementation are given below.

Step 1. Forming a group of experts and/or decision makers (Table 2). A series of focus group meetings was conducted with company owners and other experts to determine their opinions and preferences with regard to the nature of the strategies and the evaluation methods of those strategies.
Step 2. A SWOT matrix was determined by carefully defining and verifying the SWOT factors and sub-factors. The constructed SWOT matrix based on the expert knowledge is presented in Table 3.

Step 3. Using the results of the SWOT analysis explained in Step 2, the authors identified all the factors affecting the Telecommunication Company according to internal and external perspectives.

After determining the strengths, weaknesses, opportunities and threats, nine alternative strategies were identified from the SWOT analysis. As shown in Table 4, fourteen (14) alternative strategies were obtained from the SWOT analysis.

Step 4. Assuming that there is no dependence among the SWOT factors, a pairwise comparison of the SWOT factors with respect to the goal (using the 1-9 scale) is conducted (Table 1). All pairwise comparisons were done with the inputs and guidance of the expert team. The global priorities of criteria, sub-criteria and alternatives were synthesized using the eigenvalue method (EM) in Table 5.

Table 3. SWOT matrix for telecommunication company

\begin{tabular}{|c|c|}
\hline External Factors & Internal Factors \\
\hline Opportunities $(\mathrm{O})$ & Strengths (S) \\
\hline $\begin{array}{l}\text { O1 - Attraction of new customers and retaining existing } \\
\text { customers. } \\
\text { O2 - Company expansion. } \\
\text { O3 - Increased range of goods and services offered. } \\
\text { O4 - Improving the quality of services and products. } \\
\text { O5 - Stronger brand image at the domestic and interna- } \\
\text { tional level. } \\
\text { O6 - Industry growth. } \\
\text { O7 - Possibilities for increasing export volumes. } \\
\text { O8 - Improvement of professional qualifications of staff. } \\
\text { O9 - More opportunities for marketing strategies. }\end{array}$ & $\begin{array}{l}\text { S1 - Great experience of the company. } \\
\text { S2 - Customer loyalty. } \\
\text { S3 - Business owners are also the company execu- } \\
\text { tives. } \\
\text { S4 - A wide range of goods and services. } \\
\text { S5 - Qualified staff. } \\
\text { S6 - Individual approach to each customer. } \\
\text { S7 - Great share of corporate clients. } \\
\text { S8 - High level of technology development. } \\
\text { S9 - Low employee turnover. }\end{array}$ \\
\hline Threats (T) & Weaknesses (W) \\
\hline $\begin{array}{l}\text { D1 - Adverse legislative changes. } \\
\text { D2 - Expansion of competition. } \\
\text { D3 - Volatile economic and political situation. } \\
\text { D4 - Loss of customers. } \\
\text { D5 - Unfavourable exchange rate. } \\
\text { D6 - Raw material price fluctuations. } \\
\text { D7 - Decrease in demand. } \\
\text { D8 - Losing of key partners. } \\
\text { D9 - Fast aging of technology. }\end{array}$ & $\begin{array}{l}\text { W1 - Large warehouse space required for goods } \\
\text { storage. } \\
\text { W2 - Weak brand. } \\
\text { W3 - Supply of products from abroad often takes a } \\
\text { lot of time. } \\
\text { W4 - Relatively little attention is devoted to mar- } \\
\text { keting activities. } \\
\text { W5 - Supplier late delivery. } \\
\text { W6 - Lack of operational planning. }\end{array}$ \\
\hline
\end{tabular}


Table 4. Alternative strategies for telecommunication company

\begin{tabular}{|l|l|}
\hline \multicolumn{1}{|c|}{ Strategies (SO) } & \multicolumn{1}{c|}{ Strategies (WO) } \\
\hline SO1 - Product range diversification. & WO1 - Considering renting a larger one warehouse \\
SO2 - Service and product quality improvement. & space. \\
SO3 - Promoting export capability with emphasis to & WO2 - Building stronger brand. \\
the emergence of new international markets. & WO3 - Improvement of logistics. \\
SO4 - Engaging marketing activities. & WO4 - Participating in development of the local in- \\
SO5 - Strengthening position on local market & dustry. \\
\hline Strategies (ST) & Strategies (WT) \\
\hline ST1 - Creating and implementing emerging technolo- & WT1 - Promoting cooperation with competitors. \\
gies in high added value products. & WT2 - Developing and implementing long-term coor- \\
ST2 - Improving competitiveness through product & dinated process of sustainable development. \\
certification. & WT3 - Establishment of financial reserves in case of a \\
ST3 - Attraction of a foreign strategic partner. & decline in demand. \\
ST4 - Creating knowledge-sharing programs. & WT4 - Focusing on new products with high added \\
& value. \\
& WT5 - Attracting new customers to existing markets \\
& (market penetration strategy). \\
\hline
\end{tabular}

Table 5. Pairwise comparison of SWOT actors in achieving the goal matrix $\mathrm{w}_{1}$

\begin{tabular}{|l|c|c|c|c|c|}
\hline \multirow{2}{*}{} & \multicolumn{4}{|c|}{ SWOT factors } & Importance \\
\cline { 2 - 6 } & $\mathrm{S}$ & $\mathrm{W}$ & $\mathrm{O}$ & $\mathrm{T}$ & $\begin{array}{c}\text { degree of } \\
\text { factors, w1 }\end{array}$ \\
\hline Strengths (S) & 1 & 3.40 & 3.85 & 8.56 & 0.56 \\
\hline Weaknesses (W) & 0.29 & 1 & 2.10 & 7.58 & 0.25 \\
\hline $\begin{array}{l}\text { Opportunities } \\
\text { (O) }\end{array}$ & 0.26 & 0.48 & 1 & 6.50 & 0.16 \\
\hline Threats (T) & 0.12 & 0.13 & 0.15 & 1 & 0.04 \\
\hline CR & & & & 0.075 \\
\hline
\end{tabular}

Step 5. Inner dependence among the SWOT factors is determined by analysing the impact of each factor on every other factor using pairwise comparisons. It is common to observe that the SWOT factors have dependent behaviours; therefore, the authors used the ANP, which is a powerful tool to handle potential interdependencies.

The interdependencies presented in Figure 2, pair wise comparison matrices are formed for the factors (Table 6). In Figure 2, weaknesses, opportunities and threats affect to strengths. Therefore, to form its pair wise comparison matrix, strengths are considered a major controlling factor and the relative importance of weaknesses, opportunities and threats is determined in controlling strengths.

Based on the identified inner dependencies, pairwise comparison matrices are formed for the factors, and are shown in Table 6. Using the computed relative importance weights, the inner dependence matrix of the SWOT factors $\left(\mathrm{W}_{2}\right)$ is constructed (Table 6).

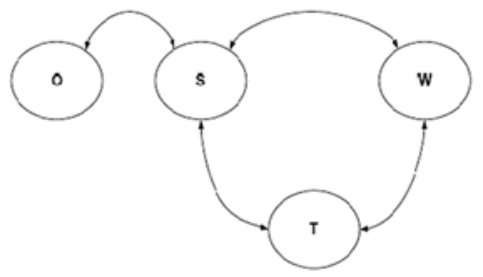

Figure 2. Representation of the SWOT factor dependencies based on Babaesmailli et al., 2012; Yüksel and Dağdeviren, 2007

Table 6. Comparison matrix $\left(\mathrm{W}_{2}\right)$ of inner dependences of SWOT factors

\begin{tabular}{|c|c|c|c|c|c|c|c|}
\hline \multirow{2}{*}{$\mathrm{S}$} & \multicolumn{7}{|c|}{ Inner dependence with respect to strengths $(\mathrm{S})$} \\
\hline & \multicolumn{2}{|c|}{ W } & \multicolumn{2}{|l|}{$\mathrm{O}$} & $\mathrm{T}$ & \multicolumn{2}{|c|}{ wi } \\
\hline $\mathrm{W}$ & \multicolumn{2}{|c|}{1} & \multicolumn{2}{|c|}{0.45} & 2.00 & \multicolumn{2}{|c|}{0.25} \\
\hline $\mathrm{O}$ & \multicolumn{2}{|c|}{2.22} & \multicolumn{2}{|l|}{1} & 7.30 & \multicolumn{2}{|c|}{0.65} \\
\hline $\mathrm{T}$ & \multicolumn{2}{|c|}{0.50} & 0.14 & & 1 & \multicolumn{2}{|c|}{0.11} \\
\hline \multicolumn{6}{|c|}{ CR } & \multicolumn{2}{|c|}{0.031} \\
\hline \multirow[t]{2}{*}{ W } & \multicolumn{3}{|c|}{$\begin{array}{l}\text { Inner dependence } \\
\text { with respect to } \\
\text { weaknesses }\end{array}$} & \multirow[t]{2}{*}{$\mathrm{T}$} & \multicolumn{3}{|c|}{$\begin{array}{c}\text { Inner dependence } \\
\text { with respect to } \\
\text { threats }\end{array}$} \\
\hline & $\mathrm{S}$ & $\mathrm{T}$ & wi & & $\mathrm{S}$ & $\mathrm{W}$ & wi \\
\hline $\mathrm{S}$ & 1 & 7.10 & 0.88 & $\mathrm{~S}$ & 1 & 5.50 & 0.847 \\
\hline $\mathrm{T}$ & 0.14 & 1 & 0.12 & W & 0.18 & 1 & 0.153 \\
\hline $\mathrm{CR}$ & & & 0 & & CR & & 0 \\
\hline
\end{tabular}

Step 6. In this step, the local importance degrees of the SWOT sub-factors (wsub-factors(local)) are calculated using the pairwise comparison matrix. 


$$
W_{\text {factors }}=W_{2} \times w_{1} \text {. }
$$

The results obtained for the factor priorities ( $w_{1}$, Table 7) with the interdependent priorities of the SWOT factors ( $\mathrm{W}_{\text {factors }}$ ) and dependencies are shown in formula 5 .

$$
W_{\text {factors }}=\{0.44,0.21 .0 .28,0.07\}^{T} .
$$

\begin{tabular}{|c|c|c|c|c|c|c|c|c|}
\hline & \multicolumn{4}{|c|}{$\begin{array}{l}\text { The comparison matrix } \\
\qquad\left(\mathrm{W}_{2}\right)\end{array}$} & \multirow[b]{3}{*}{$x$} & \multirow{2}{*}{$\mathrm{w}_{1}$} & \multirow[b]{3}{*}{$=$} & \multirow{2}{*}{$\mathrm{W}_{2} \times \mathrm{W}_{1}$} \\
\hline & $\mathrm{S}$ & $\mathrm{W}$ & $\mathrm{O}$ & $\mathrm{T}$ & & & & \\
\hline $\mathrm{S}$ & 1 & 0.88 & 0.00 & 0.85 & & 0.56 & & 0.80 \\
\hline W & 0.25 & 1 & 0.00 & 0.15 & & 0.25 & & 0.39 \\
\hline $\mathrm{O}$ & 0.65 & 0.00 & 1.00 & 0.00 & & 0.16 & & 0.52 \\
\hline $\mathrm{T}$ & 0.11 & 0.12 & 0.00 & 1.00 & & 0.04 & & 0.13 \\
\hline & & & & & & & & 1.84 \\
\hline
\end{tabular}

Table 7. Interdependent priorities of SWOT factors

Step 7. Here, the overall weights of the SWOT sub-factors (wsub-factors(global)) were determined by multiplying the interdependent priorities of SWOT factors found in Step 5 with the local priorities of SWOT sub-factors obtained in Step 6. The priorities are shown in Table 8.

Table 8. Conversion of local priorities of sub-factors

\begin{tabular}{|c|c|c|c|c|}
\hline \multirow{2}{*}{ 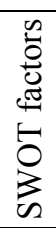 } & \multirow[b]{2}{*}{$\begin{array}{l}\text { Priority } \\
\text { of the } \\
\text { factors } \\
\text { (wfakt.) }\end{array}$} & \multirow[b]{2}{*}{$\begin{array}{l}\text { SWOT } \\
\text { sub- } \\
\text { factors }\end{array}$} & \multicolumn{2}{|c|}{ Priority of the sub-factors } \\
\hline & & & $\begin{array}{c}\text { Local } \\
\text { (WSub-fact.) }\end{array}$ & $\begin{array}{c}\text { Global } \\
\left(\mathrm{w}_{\text {sub- }}\right. \\
\text { fact(globall) })\end{array}$ \\
\hline \multirow{9}{*}{ 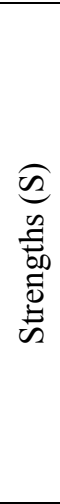 } & \multirow{9}{*}{0.44} & $\mathrm{~S}_{1}$ & 0.22 & 0.10 \\
\hline & & $\mathrm{S}_{2}$ & 0.12 & 0.05 \\
\hline & & $\mathrm{S}_{3}$ & 0.02 & 0.01 \\
\hline & & $\mathrm{S}_{4}$ & 0.12 & 0.05 \\
\hline & & $\mathrm{S}_{5}$ & 0.08 & 0.04 \\
\hline & & $\mathrm{S}_{6}$ & 0.07 & 0.03 \\
\hline & & $\mathrm{S}_{7}$ & 0.05 & 0.02 \\
\hline & & $\mathrm{S}_{8}$ & 0.20 & 0.09 \\
\hline & & $\mathrm{S}_{9}$ & 0.11 & 0.05 \\
\hline \multirow{6}{*}{$\begin{array}{l}\text { } \\
0 \\
0 \\
0 \\
0 \\
\Xi \\
\tilde{0} \\
0 \\
3\end{array}$} & \multirow{6}{*}{0.21} & $\mathrm{~W}_{1}$ & 0.17 & 0.04 \\
\hline & & $\mathrm{W}_{2}$ & 0.07 & 0.02 \\
\hline & & $\mathrm{W}_{3}$ & 0.10 & 0.02 \\
\hline & & $\mathrm{W}_{4}$ & 0.11 & 0.02 \\
\hline & & $\mathrm{W}_{5}$ & 0,29 & 0.06 \\
\hline & & $\mathrm{W}_{6}$ & 0.25 & 0.05 \\
\hline
\end{tabular}
into global priorities (ANP)

\begin{tabular}{|c|c|c|c|c|}
\hline \multirow{2}{*}{ 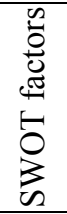 } & \multirow{2}{*}{$\begin{array}{l}\text { Priority } \\
\text { of the } \\
\text { factors } \\
\left.\text { (w } \mathbf{w}_{\text {fakt. }}\right)\end{array}$} & \multirow[b]{2}{*}{$\begin{array}{l}\text { SWOT } \\
\text { sub- } \\
\text { factors }\end{array}$} & \multicolumn{2}{|c|}{ Priority of the sub-factors } \\
\hline & & & $\begin{array}{c}\text { Local } \\
\left(\mathrm{w}_{\text {Sub-fact. }}\right)\end{array}$ & $\begin{array}{c}\text { Global } \\
\left(\mathrm{w}_{\text {sub- }}\right. \\
\text { fact(globall })\end{array}$ \\
\hline \multirow{9}{*}{ 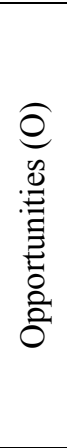 } & \multirow{9}{*}{0.28} & $\mathrm{O}_{1}$ & 0.17 & 0.05 \\
\hline & & $\mathrm{O}_{2}$ & 0.05 & 0.01 \\
\hline & & $\mathrm{O}_{3}$ & 0.04 & 0.01 \\
\hline & & $\mathrm{O}_{4}$ & 0.10 & 0.03 \\
\hline & & $\mathrm{O}_{5}$ & 0.14 & 0.04 \\
\hline & & $\mathrm{O}_{6}$ & 0.09 & 0.03 \\
\hline & & $\mathrm{O}_{7}$ & 0.28 & 0.08 \\
\hline & & $\mathrm{O}_{8}$ & 0.10 & 0.03 \\
\hline & & $\mathrm{O}_{9}$ & 0.04 & 0.01 \\
\hline \multirow{9}{*}{ 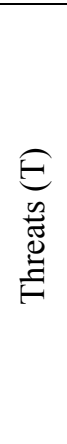 } & \multirow{9}{*}{0.07} & $\mathrm{~T}_{1}$ & 0.24 & 0.02 \\
\hline & & $\mathrm{T}_{2}$ & 0.11 & 0.01 \\
\hline & & $\mathrm{T}_{3}$ & 0.09 & 0.01 \\
\hline & & $\mathrm{T}_{4}$ & 0.15 & 0.01 \\
\hline & & $\mathrm{T}_{5}$ & 0.09 & 0.01 \\
\hline & & $\mathrm{T}_{6}$ & 0.07 & 0.00 \\
\hline & & $\mathrm{T}_{7}$ & 0.11 & 0.01 \\
\hline & & $\mathrm{T}_{8}$ & 0.09 & 0.01 \\
\hline & & $\mathrm{T}_{9}$ & 0,05 & 0,00 \\
\hline $\begin{array}{l}\text { To- } \\
\text { tal }\end{array}$ & 1.00 & & 4.00 & 1.00 \\
\hline
\end{tabular}

End of Table 8

Step 8. In this step, the evaluation matrix was obtained, with regard to the alternatives and SWOT sub-factors, using the variables provided by the expert team (Table 9).

Based on a huge number of sub-factors (32) and the proposed company development strategies (18), and as a result of numerous pairwise comparisons, the expert committee decided to use $\mathrm{SO}$, WO, ST and WT group decision voting principle. Group evaluation of sub-factors for strategies SO, WO, ST and WT using the scale 1-9 are given in Table 9.

Table 9. Evaluation of sub-factors using the variables provided by the expert team

\begin{tabular}{|l|c|c|c|c|c|c|}
\hline \multicolumn{1}{|c|}{$\mathrm{S}_{1}$} & SO & WO & & ST & WT & $\begin{array}{c}\text { Local } \\
\text { weights }\end{array}$ \\
\hline SO Strategy & 1.00 & 6.00 & & 4.00 & 9.00 & 0.64 \\
\hline $\begin{array}{l}\text { WO } \\
\text { Strategy }\end{array}$ & 0.17 & 1.00 & & 0.50 & 2.00 & 0.11 \\
\hline ST Strategy & 0.25 & 2.00 & & 1.00 & 3.00 & 0.19 \\
\hline WT Strategy & 0.11 & 0.50 & & 0.33 & 1.00 & 0.06 \\
\hline \multicolumn{7}{|c|}{$C R=0.0075$} \\
\hline
\end{tabular}


Using expert evaluation (Table 9) of sub-factor importance degrees to the alternative strategies $\mathrm{SO}, \mathrm{WO}, \mathrm{ST}$ and WT, the matrix $W_{4}$ was constructed:

$W_{4}=\left[\begin{array}{ccccccc}0.64 & 0.49 & 0.35 & \ldots & 0.28 & 0.33 & 0.39 \\ 0.11 & 0.13 & 0.10 & \ldots & 0.24 & 0.16 & 0.16 \\ 0.19 & 0.26 & 0.32 & \ldots & 0.34 & 0.41 & 0.29 \\ 0.06 & 0.12 & 0.24 & \ldots & 0.14 & 0.11 & 0.16\end{array}\right]$.

Finally, the overall priorities of the alternative strategies, reflecting the interrelationships within the SWOT factors, are calculated as follows:

$W_{\text {alternatives }}=\left\{\begin{array}{c}S O \\ W O \\ S T \\ W T\end{array}\right\}=W_{4} \times w_{\text {sub-fact (global })}=\left\{\begin{array}{c}0.47 \\ 0.15 \\ 0.24 \\ 0.12\end{array}\right\}$.

The ANP analysis results indicate that $\mathrm{SO}$ is the best strategy with an overall priority value of 0.47 .

When comparing overall priorities of the $\mathrm{SO}$, WO, ST and WT, they were assessed without ANP interdependent priorities (see Table 10).

By comparing overall priorities of the SO, WO, ST and WT without ANP interdependent priorities, they did not show major differences.

Table 10. Evaluation of SO, WO, ST and WT with AHP and ANP

\begin{tabular}{|l|c|c|c|c|}
\hline & SO & WO & ST & WT \\
\hline Weights in ANP & 0.469 & 0.151 & 0.242 & 0.136 \\
\hline Ranking in ANP & 1 & 3 & 2 & 4 \\
\hline Weights in AHP & 0.485 & 0.147 & 0.237 & 0.131 \\
\hline Ranking in AHP & 1 & 3 & 2 & 4 \\
\hline
\end{tabular}

Step 9. In this step, the interdependence of sub-strategies was evaluated using AHP.

Expert committee, using the scale 1-9, obtained the local priorities of the alternative SO, WO, ST and WT strategies of sub-factors for strategies SO, WO, ST and WT. The results are given in Table 9. Example of the local priorities of the alternative SO strategies is given in Table 11 .

According to the tabulated results, the third strategy had the highest closeness coefficient with the value of 0.227 . Accordingly, "SO1-SO2SO3-WO3-ST3: selection" came out as the best (most preferred/valued) strategy from the SWOT analysis.
Table 11. Local priorities of alternative SO strategies

\begin{tabular}{|l|l|l|l|l|l|c|}
\hline & SO1 & SO2 & SO3 & SO4 & SO5 & $\begin{array}{c}\text { Local } \\
\text { weights Wst }\end{array}$ \\
\hline SO1 & 1.00 & 0.50 & 0.33 & 3.00 & 2.00 & 0.15 \\
\hline SO2 & 2.00 & 1.00 & 0.33 & 4.00 & 3.00 & 0.23 \\
\hline SO3 & 3.03 & 3.03 & 1.00 & 6.00 & 6,00 & 0.48 \\
\hline SO4 & 0.33 & 0.25 & 0.17 & 1.00 & 1.00 & 0.06 \\
\hline SO5 & 0.50 & 0.33 & 0.17 & 1.00 & 1.00 & 0.07 \\
\hline \multicolumn{7}{|c|}{ CR $=0.017$} \\
\hline
\end{tabular}

Step 10. In this step, sub-strategies were ranked according to overall priority. Conversion of local priorities of sub-strategies to overall priority and their ranking are given in Table 12 . The ranking of the alternatives in descending order came out to be Strategy 3, Strategy 12, Strategy 2, Strategy 1, Strategy 8, Strategy 16 (SO3 - ST3 SO2 - SO1 - WO3 - WT3).

Step 11. In last step, the best strategy is determined as "Strategy 3 (SO3): Promoting export capability with emphasis to the emergence of new international markets". According to the calculated ranking values (see Table 8), it can be concluded that Strategy 3 (SO3) is in the first/ highest priority. SO3 ranked higher than the other strategies with a priority value of 0.294 . Strategy ST3 (Attraction of a foreign strategic partner) came as the second highest priority with a ranking value of 0.139 .

Table 12. Overall priorities of alternative strategies

\begin{tabular}{|c|c|c|c|c|c|}
\hline \multirow[b]{2}{*}{$\begin{array}{c}\text { Group } \\
\text { of the } \\
\text { Strat- } \\
\text { egy }\end{array}$} & \multirow{2}{*}{$\begin{array}{l}\text { Prior- } \\
\text { ity of } \\
\text { the } \\
\text { strat- } \\
\text { egy }\end{array}$} & \multicolumn{4}{|c|}{ The sub-strategy } \\
\hline & & $\begin{array}{l}\text { Strat- } \\
\text { egies }\end{array}$ & $\begin{array}{c}\text { Lo- } \\
\text { cal } \\
\text { prio- } \\
\text { rity }\end{array}$ & $\begin{array}{l}\text { Over- } \\
\text { all } \\
\text { prior- } \\
\text { ity }\end{array}$ & Rank \\
\hline \multirow[t]{5}{*}{$\mathrm{SO}$} & 0.47 & SO1 & 0.15 & 0.071 & 4 \\
\hline & & $\mathrm{SO} 2$ & 0.23 & 0.108 & 3 \\
\hline & & $\mathrm{SO} 3$ & 0.48 & 0.227 & 1 \\
\hline & & $\mathrm{SO} 4$ & 0.06 & 0.030 & 11 \\
\hline & & SO5 & 0.07 & 0.034 & 10 \\
\hline \multirow[t]{4}{*}{ WO } & 0.15 & WO1 & 0.33 & 0.050 & 7 \\
\hline & & WO2 & 0.15 & 0.022 & 13 \\
\hline & & WO3 & 0.43 & 0.065 & 5 \\
\hline & & WO4 & 0.08 & 0.013 & 17 \\
\hline \multirow[t]{4}{*}{$\mathrm{ST}$} & 0.24 & ST1 & 0.17 & 0.041 & 9 \\
\hline & & ST2 & 0.17 & 0.041 & 9 \\
\hline & & ST3 & 0.58 & 0.139 & 2 \\
\hline & & ST4 & 0.08 & 0.018 & 16 \\
\hline
\end{tabular}


End of Table 12

\begin{tabular}{|c|c|c|c|c|c|}
\hline \multirow[b]{2}{*}{$\begin{array}{c}\text { Group } \\
\text { of the } \\
\text { Strat- } \\
\text { egy }\end{array}$} & \multirow{2}{*}{$\begin{array}{l}\text { Prior- } \\
\text { ity of } \\
\text { the } \\
\text { strat- } \\
\text { egy }\end{array}$} & \multicolumn{4}{|c|}{ The sub-strategy } \\
\hline & & $\begin{array}{l}\text { Strat- } \\
\text { egies }\end{array}$ & $\begin{array}{c}\text { Lo- } \\
\text { cal } \\
\text { prio- } \\
\text { rity }\end{array}$ & $\begin{array}{l}\text { Over- } \\
\text { all } \\
\text { prior- } \\
\text { ity }\end{array}$ & Rank \\
\hline \multirow[t]{5}{*}{ WT } & 0.12 & WT1 & 0.21 & 0.029 & 12 \\
\hline & & WT2 & 0.07 & 0.010 & 18 \\
\hline & & WT3 & 0.39 & 0.055 & 6 \\
\hline & & WT4 & 0.20 & 0.027 & 14 \\
\hline & & WT5 & 0.13 & 0.018 & 16 \\
\hline \multicolumn{3}{|c|}{ Total } & 4.00 & 1.00 & \\
\hline
\end{tabular}

The second strategy "Attraction of a foreign strategic partner" (ST3) is very close and connected to the first one. Third, fourth and fifth strategies, which are "Service and product quality improvement" (SO2), "Product range diversifycation" (SO1) and "Improvement of logistics" (WO3) also relate to each other. In other words, they all support one another. Using high quality equipment and products, it is important to support product management in order to increase efficiency. Surprisingly increasing R\&D activities "Creating and implementing emerging technologies in high added value products" (ST1) are not valued highly. Advance technology investments decrease the inefficiency of the Telecommunication system, and thus is coordinated with Telecommunication planning/management effectively. This strategy usually contributes most in comparison with other strategies. The reason is obvious for local companies. $R \& D$ activities require advanced investment strategies, have investment lag and high risk of failure. Local companies are trying to avoid high risks and remain in the position of technology followers. Adoption of contemporary technologies (technology transfer) is considered more competitive when compared to investment rentability. Next strategy also explains the reason to cease R\&D activities. In order to reduce dependence on market demand, some critical implementations have been discussed (Establishment of financial reserves in case of a decline in demand). "Establishment of financial reserves in case of a decline in demand" (WT3) is the sixth strategy. Dynamics of technologies and improvement of efficiency contribute to the volatility of the environment. In this respect, financial reserves seem to be one of the most efficient and prominent alternatives for company development in Latvia when compared to $R \& D$ activities. This is also a more defensive way of strategic behaviour.

\section{Conclusions}

The present paper has provided a detailed framework for prioritisation of competitive strategies based on the ANP approach for the Latvian market. Some advantages and peculiarities among SWOT hybrid methods have also been discussed in the paper.

Firstly, the authors have observed a variety of SWOT hybrid methods (AHP, ANP, FANP, TOPSIS, DEMATEL, PROMETHEE, ELECTRE, etc.), which are among the most commonly used MCDA techniques. High entrance barriers have been recognised for smaller companies working with more sophisticated techniques (e.g., knowledge of Markov chain process).

Secondly, the important conclusion associated with the assessment of super-matrices (Saaty, 2005) has been drawn and a different technique has been proposed, which is more convenient for smaller companies. The process of formation of expert groups has been explained in order to assess SWOT factors and select strategies. Thirdly, strategic planning problems have been discussed in the scientific literature. Fast response of strategies to rapidly changing market conditions becomes the most demanded topic. Within the framework of the present research, an integrated SWOT-AHP framework has been proposed for the Telecommunication company using the SWOT analysis augmented with the ANP methodology to obtain criteria weights and prioritize alternative strategies, which could be used even for small companies.

Finally, according to the empirical results of the SWOT-ANP weighted analytic methodology, "Promoting export capability with emphasis to the emergence of new international markets" (SO3) ranks as the first priority for company. The second strategy "Attraction of a foreign strategic partner" (ST3) is very close and connected to the first one. Strategy SO2 (Service and product quality improvement) is the third highest with a priority rank value of 0.108 . It should be noted that investments to technologies are very important, but have some peculiarities on the local market. All the results of the proposed integrated SWOT- ANP approach show greater support of existing products and their development, rather than enhanced R\&D activities.

The limitations of the research could be discussed since Latvia has a specific geo-political and economic position (Global Innovation Index 44 out of 127 and, compared to other EU coun- 
tries, Latvian R\&D expenditure is greatly reduced, $0.4 \%$ of the GDP in 2016 (EU, 2018; WIPO, 2017)). Future research in the Baltic States could confirm or reject this limitation. Latvia is a good case for analysis since it has open market with perfect logistic value chains and works as a bridge between Eastern and Western Europe. For this reason, the research results are crucial for Telecommunication companies in small countries with the target of becoming both a locally and an internationally competitive in the European markets.

As for practical implication of the research case, it allows even small Telecommunication companies to assess their strategies with the ANP-SWOT method and follow the discussed defensive strategies both for the domestic and international market.

\section{References}

Al-Refaie, A., Sy, E., Rawabdeh, I., \& Alaween, W. (2016). Integration of SWOT and ANP for effective strategic planning in the cosmetic industry. Advances in Production Engineering \& Management, 11, 49-58. https://doi.org/10.14743/apem2016.1.209

Andrews, K. R. (1971). The concept of corporate strategy. Dow Jones-Irwin: Homewood III, CA, USA.

Arshadikhamseh, A., \& Fazayeli, M. (2013). A fuzzy analytical network process for SWOT analysis (case study: drug distribution company). Technical Journal of Engineering and Applied Sciences, 3, 2317-2326.

Arsić, S., Nikolić, D., Mihajlović, I., Fedajev, A., \& Živković, Ž. (2018). A new approach within ANP-SWOT framework for prioritization of ecosystem management and case study of national park Djerdap, Serbia. Ecological Economics, 146, 85-95. https://doi.org/10.1016/j.ecolecon.2017.10.006

Arsić, S., Nikolić, D., \& Živković, Z. (2017). Hybrid SWOT - ANP - FANP model for prioritization strategies of sustainable development of ecotourism in national park Djerdap, Serbia. Forest Policy and Economics, 80, 11-26.

https://doi.org/10.1016/j.forpol.2017.02.003

Babaesmailli, M., Arbabshirani, B., \& Golmah, V. (2012). Integrating analytical network process and fuzzy logic to prioritize the strategies - a case study for tile manufacturing firm. Expert Systems with Applications, 39, 925-935. https://doi.org/10.1016/j.eswa.2011.07.090

Cayir Ervural, B., Zaim, S., Demirel, O. F., Aydin, Z., \& Delen, D. (2018). An ANP and fuzzy TOPSIS-based SWOT analysis for Turkey's energy planning. Renewable and Sustainable Energy Reviews, 82, 1538-1550.

Catron, J., Stainback, G. A., Dwivedi, P., \& Lhotka, J. M. (2013). Bioenergy development in Kentucky: a SWOT-ANP analysis. Forest Policy and Economics, $28,38-43$. https://doi.org/10.1016/j.forpol.2012.12.003

Cebeci, U. (2009). Fuzzy AHP-based decision support system for selecting ERP systems in textile industry by using balanced scorecard. Expert Systems Applications, $36,8900-8909$.

https://doi.org/10.1016/j.eswa.2008.11.046
Chen, J., \& Yang, Y. (2011). A fuzzy ANP-based approach to evaluate region agricultural drought risk. Procedia Engineering, 23, 822-827. https://doi.org/10.1016/j.proeng.2011.11.2588

Di Lallo, G., Maesano, M., Masiero, M., Mugnozza, G. S., \& Marchetti, M. (2016). Analyzing strategies to enhance small and low intensity managed forests certification in Europe using SWOT-ANP. Small-scale Forestry, 15(3), 393-411. https://doi.org/10.1007/s11842-016-9329-y

EU. (2018). Total intramural R\&D expenditure (GERD) and R\&D intensity - Latvia. Retrieved from https://rio.jrc .ec.europa.eu/country-analysis/Latvia/key-indicators $/ 25574$

Fouladgar, M. M., Yazdani-Chamzini, A., \& Zavadskas, E. K. (2011). An integrated model for prioritizing strategies of the iranian mining sector. Technological and Economic Development of Economy, 17, 459-483. https://doi.org/10.3846/20294913.2011.603173

Gottfried, O., De Clercq, D., Blair, E., Weng, X., \& Wang, C. (2018). SWOT-AHP-TOWS analysis of private investment behavior in the Chinese biogas sector. Journal of Cleaner Production, 184, 632-647. https://doi.org/10.1016/j.jclepro.2018.02.173

Grošelj, P., \& Zadnik Stirn, L. (2015). The environmental management problem of Pohorje, Slovenia: a new group approach within ANP - SWOT framework. Journal of Environmental Management, 161, 106-112. https://doi.org/10.1016/j.jenvman.2015.06.038

Haile, M., \& Krupka, J. (2016, April). Modelling of SWOT analysis using Fuzzy integrals. International Conference of Soft Science. Kedac, Malaysia. https://doi.org/10.15405/epsbs.2016.08.12

Hejazi, S., \& Lak, E. (2014). Determining priorities of effective organizational strategies by ANP and SWOT models. European Journal of Business and Management, 6(1), 115-128.

Hill, T., \& Westbrook, R. (1997). SWOT analysis: it's time for a product recall. Long Range Plan, 30, 46-52.

Ho, W. (2008). Integrated analytic hierarchy process and its applications - a literature review. European Journal of Operational Research, 186, 211-228. https://doi.org/10.1016/j.ejor.2007.01.004

Yang, Y., Shieh, H., Leu, J., \& Tzeng, G.-H. (2008). A novel hybrid MCDM model combined with DEMATEL and ANP with applications. International Journal of Operations Research, 5, 160-168.

Yüksel, I., \& Dağdeviren, M. (2007). Using the analytic network process (ANP) in a SWOT analysis - a case study for a textile firm. Information Sciences, 177, 33643382.

Ivlev, I., Kneppo, P., \& Barták, M. (2015). Method for selecting expert groups and determining the importance of experts' judgments for the purpose of managerial decision-making tasks in health system. Business Administration and Management, 18, 57-72. https://doi.org/10.15240/tul/001/2015-2-005

Kurttila, M., Pesonen, M., Kangas, J., \& Kajanus, M. (2000). Utilizing the analytic hierarchy process (AHP) in SWOT analysis - a hybrid method and its application to a forest-certification case. Forest Policy and Economics, 1, 41-52. https://doi.org/10.1016/S1389-9341(99)00004-0

Merton, R. K., Fiske, M., \& Kendall, P. L. (1990). The focused interview: a manual of problems and procedures. Published by Free Press. 
Moghimi, H. R., Sobhanollahi, M. A., \& Ghodratnama, A. (2014). ANP-based strategic planning for Iran's Trade Promotion Organization. International Journal of Engineering, Transactions B: Applications, 27, 12151222.

https://doi.org/10.5829/idosi.ije.2014.27.08b.07

Postnikov, V., \& Spiridonov, S. (2013). Approach to increasing the level of consistency of expert opinion when selecting the variant of development of the data processing system. Science and Education of the Bauman MSTU, 13, 333-350.

https://doi.org/10.7463/0613.0574220

Ren, J., Gao, S., Tan, S., \& Dong, L. (2015a). Hydrogen economy in China: strengths-weaknesses-opportunities-threats analysis and strategies prioritization. Renewable and Sustainable Energy Reviews, 41, 12301233. https://doi.org/10.1016/j.rser.2014.09.014

Ren, J., Tan, S., Goodsite, M. E., Sovacool, B. K., \& Dong, L. (2015b). Sustainability, shale gas, and energy transition in China: assessing barriers and prioritizing strategic measures. Energy, 84, 551-562. https://doi.org/10.1016/j.energy.2015.03.020

Saaty, T. L. (2005). Theory and applications of the analytic network process: decision making with benefits, opportunities, costs, and risks. Pittsburgh: RWS Publications.

Saaty, T. L. (2004). Decision making - the analytic hierarchy and network processes (AHP/ANP). Journal of Systems Science and Systems Engineering, 13, 1-35. https://doi.org/10.1007/s11518-006-0151-5

Saaty, T. L. (1989). Decision making for leaders: the analytical hierarchy process for decisions in a complex world. European Journal of Operational Research, 42, 107109. https://doi.org/10.1016/0377-2217(89)90066-0
Sevkli, M., Oztekin, A., Uysal, O., Torlak, G., Turkyilmaz, A., \& Delen, D. (2012). Development of a fuzzy ANP based SWOT analysis for the airline industry in Turkey. Expert Systems with Applications, 39, 14-24. https://doi.org/10.1016/j.eswa.2011.06.047

Shahabi, R. S., Basiri, M. H., Kahag, M. R., \& Zonouzi, S. A. (2014). An ANP-SWOT approach for interdependency analysis and prioritizing the Iran's steel scrap industry strategies. Resources Policy, 42, 18-26. https://doi.org/10.1016/j.resourpol.2014.07.001

Wang, X., Li, C., Shang, J., Yang, C., Zhang, B., \& Ke, X. (2017). Strategic choices of China's new energy vehicle industry: an analysis based on ANP and SWOT. Energies, 10, 1-27. https://doi.org/10.3390/en10040537

Wang, X., Liu, Z., \& Cai, Y. (2015). A rating based fuzzy analytic network process (F-ANP) model for evaluation of ship maneuverability. Ocean Engineering, 106, 39-46. https://doi.org/10.1016/j.oceaneng.2015.06.061

Wijnmalen, D. J. D. (2007). Analysis of benefits, opportunities, costs, and risks (BOCR) with the AHP-ANP: a critical validation. Mathematical and Computer Modelling, 46, 892-905. https://doi.org/10.1016/j.mcm.2007.03.020

WIPO. (2017). The global innovation index 2017 (10th ed.). World Intellectual Property Organization (WIPO), Geneva, Switzerland.

Zhü, K., Zhao, S. Yao, Yang, S., Liang, C., \& Gu, D. (2016). Where is the way for rare earth industry of China: an analysis via ANP-SWOT approach. Resources Policy, 49, 349-357.

Živković, Ž., Nikolić, D., Djordjević, P., Mihajlović, I., \& Savić, M. (2015). Analytical network process in the framework of SWOT analysis for strategic decision making. Acta Polytechnica Hungarica, 12, 199-216. https://doi.org/10.12700/APH 